\title{
A design to improve the comparability of area maps: the example of the premature mortality in Belgium
}

\author{
Francoise Renard ${ }^{1 *}$, Patrick Deboosere ${ }^{2}$, Jean Tafforeau ${ }^{1}$ \\ From Methods in Epidemiology Symposium \\ Leuven, Belgium. 17 September 2015
}

\begin{abstract}
Methods
A diverging green-to-red colour scale is used, where the cut-off colour (yellow) represents a reference value with the same meaning across all maps: the average sex-specific mortality rate for the cause of death studied. To represent the relative disparity, rates are classified according to a geometric progression with a $1.1 \mathrm{step}$, meaning that each colour class has a mortality rate 1.1 times higher than the preceding one. The number of classes is determined by the disparity between the extreme districts: the larger the disparity, the more colour classes present and the sharper the colour contrast. The relative distance between the highest and the lowest classes is 1.1 The midpoint of each class is calculated as the average rate * (1.1) rank of the class, starting from the average. The legend of the maps displays the boundaries of each class.
\end{abstract}

\section{Results}

The all-causes premature mortality map displays $8 \mathrm{col}-$ our classes in males and 6 in females, expressing a stronger between-district disparity in men $(R R=1.8)$ than in women $(R R=1.6)$. The highest class (observed in Mons and Charleroi) ranks at the $4^{\text {th }}$ position above the average (being 490.6 per 100.000). The midpoint of this highest class is calculated as $490.6^{*}\left(1.1^{4}\right)=718$ per 100.000. The lowest rate is observed in Maaseik ( $3^{\text {rd }}$ class below the average). The midpoint of this lowest class is $490.6^{*}\left(1.1^{-3}\right)=368.5$ per 100.000 .

'The Scientific Institute of Public Health WIV-ISP, Brussels, Belgium Full list of author information is available at the end of the article

\section{Conclusion}

The use of a relative scale allows an easy comparison between maps and shows at a glance the relative between-district disparity.

\section{Authors' details \\ ${ }^{1}$ The Scientific Institute of Public Health WIV-ISP, Brussels, Belgium. ${ }^{2}$ Vrije Universiteit, Brussels, Belgium.}

Published: 17 September 2015

doi:10.1186/2049-3258-73-S1-P32

Cite this article as: Renard et al:. A design to improve the comparability of area maps: the example of the premature mortality in Belgium. Archives of Public Health 2015 73(Suppl 1):P32.
Submit your next manuscript to BioMed Central and take full advantage of:

- Convenient online submission

- Thorough peer review

- No space constraints or color figure charges

- Immediate publication on acceptance

- Inclusion in PubMed, CAS, Scopus and Google Scholar

- Research which is freely available for redistribution
() Biomed Central
C Biomed Central (c) 2015 Renard et al. This is an Open Access article distributed under the terms of the Creative Commons Attribution License (http://
creativecommons.org/licenses/by/4.0), which permits unrestricted use, distribution, and reproduction in any medium, provided the original work is properly cited. The Creative Commons Public Domain Dedication waiver (http://creativecommons.org/publicdomain/ zero/1.0/) applies to the data made available in this article, unless otherwise stated. 